\title{
Characterization of Deleterious Expansive Reactions in Fagilde Dam
}

\author{
Isabel Fernandes • António Santos Silva • \\ José Piteira Gomes • António Tavares de Castro • \\ Fernando Noronha $\cdot$ Maria dos Anjos Ribeiro
}

Received: 30 May 2013/Revised: 22 August 2013/Accepted: 30 August 2013/Published online: 3 October 2013

(C) Springer Science+Business Media New York and ASM International 2013

\begin{abstract}
A monitoring system has been detecting progressive displacements in Fagilde dam, completed in 1984. Site inspection revealed the existence of random cracking, surface discoloration, and superficial dissolution of cement in the spillway surfaces and in the upstream face of the dam. The macroscopic signs of deterioration, which could be due to different mechanisms, showed an uneven distribution in the exposed surfaces of the structure. Crushed limestone and alluvial siliceous sand were used as aggregates. Alkali-aggregate reaction was considered to be the likely cause of concrete distress. In order to investigate the causes of cracking and of the movements registered in the wall, drill core sampling was performed and the concrete investigated for the occurrence of expansive reactions. Concrete petrography was complemented by other tests in order to assess the probable evolution of the reactions in the structure in the near future. Residual expansion tests, soluble alkalis evaluation, and unconfined compression tests were carried out. Alkali-aggregate reactions and internal sulfate reaction were considered to be the main causes of damage in the concrete. In this study, microscopy showed to be an essential tool in the identification of the main causes of deterioration.
\end{abstract}

Keywords Displacement - Microscopy $\cdot$ Laboratory tests - Internal sulfate reaction - Alkali-aggregate reaction

I. Fernandes $(\bowtie) \cdot$ F. Noronha $\cdot$ M. dos Anjos Ribeiro DGAOT/Centre of Geology, University of Porto, Rua do Campo Alegre, 4169-007 Porto, Portugal

e-mail: ifernand@fc.up.pt

A. S. Silva · J. P. Gomes - A. T. de Castro

National Laboratory for Civil Engineering, Av. do Brasil 101, 1700-066 Lisbon, Portugal

\section{Introduction}

The structure that has been studied is a concrete dam built in the early 1980s, in the center of Portugal, with a $26.6 \mathrm{~m}$ maximum height over the foundation. The Fagilde dam is composed of two central spillways and three buttresses, with arch sections at each side, having vertical upstream walls and artificial concrete abutments (Fig. 1). The initial impoundment of the dam reservoir occurred from June 1985 to January 1987.

The dam monitoring system was designed for measurement of the water level in the reservoir, atmospheric temperature, uplift water pressure, horizontal and vertical displacements by geodetic methods, joint movements, and drainage flow through the foundation. In the beginning of the 1990s, irreversible vertical upward and horizontal upstream displacements were registered, indicating incipient deformation. Due to the occurrence of these irreversible displacements, a research program was planned in 2003 aiming to identify the main causes of the deterioration and evaluate the future development of the deterioration process. Figure 2 presents the component of vertical displacement, which can be attributed to the time effects, at five points located in the crest on three different dates (2000, 2007, and 2012), showing the upward crest movements over time. The vertical displacements of these points are evaluated by precision leveling. By making use of a statistical model, to separate the effects of the main actions, it is possible to identify the components due to variation in the water level in the reservoir, the air temperature, and the time effects. This latter component is usually associated with creep and/or deterioration processes. As shown in Fig. 2, the largest displacements occur at point $1 \mathrm{D}$, located on the highest part of the right arch next to the joint $\mathrm{J} 2$. This vertical displacement 
a

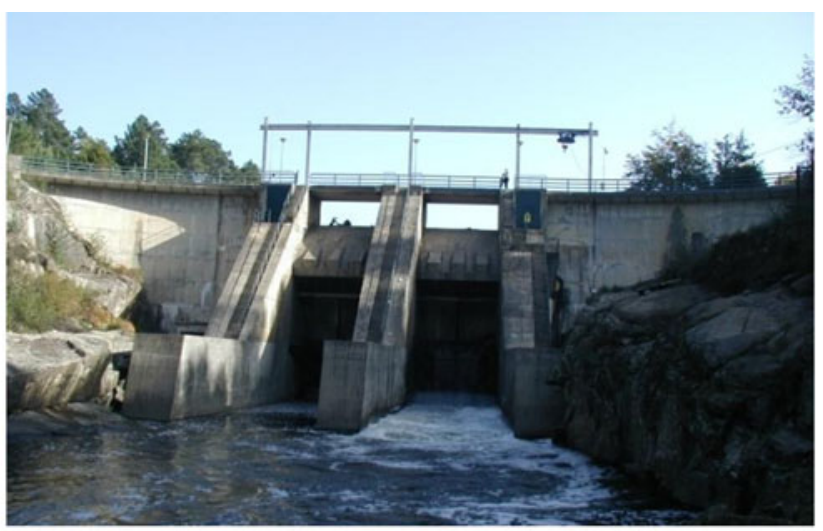

b
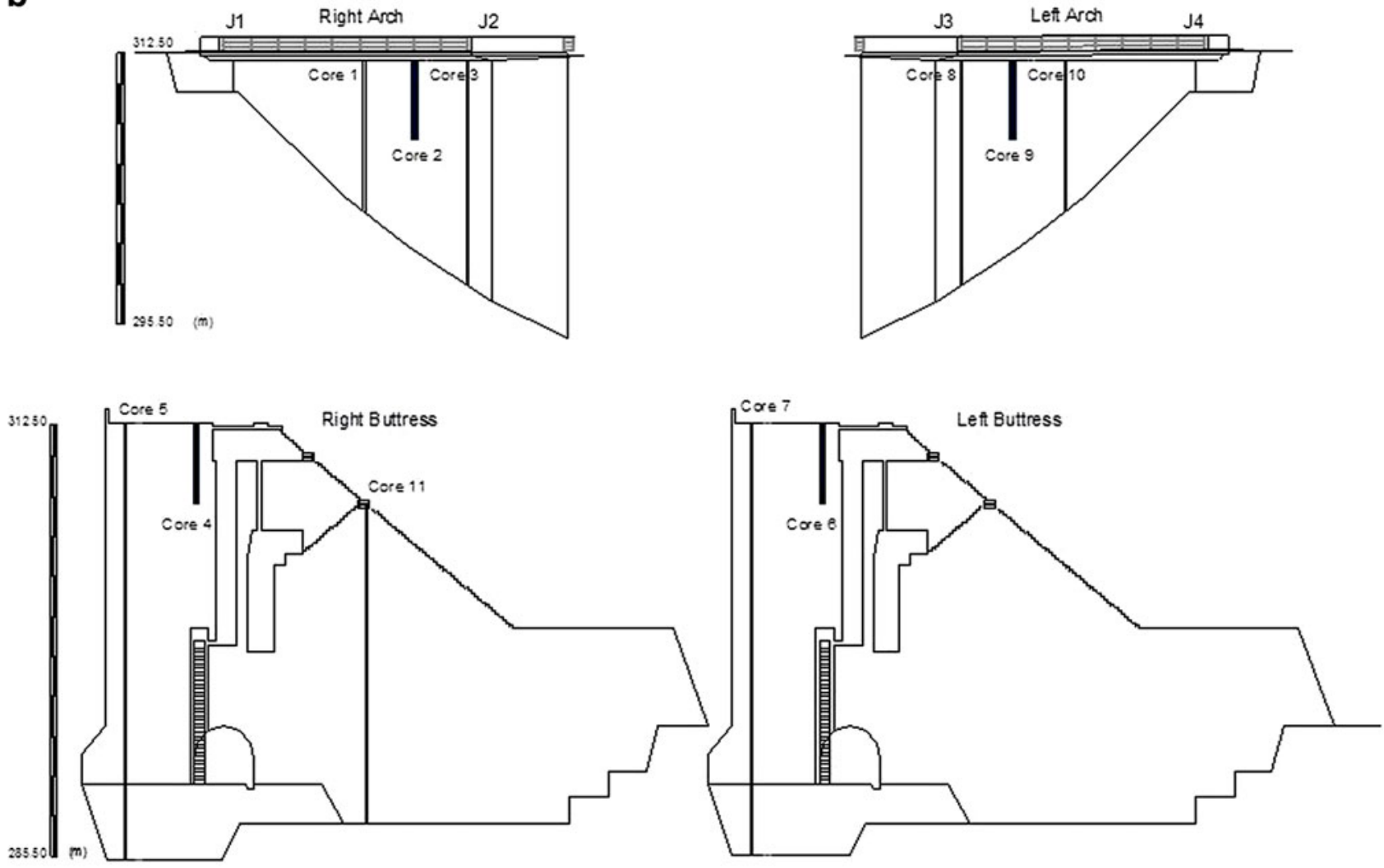

Fig. 1 Image of the dam in a view from downstream. In the drawings, there are the indications of the joints (J1, J2, etc.) and the indication of the drill cores locations. The shorter cores are of larger diameter $(150 \mathrm{~mm})$

corresponds, in 2012, to an accumulated swelling of approximately $2,000 \times 10^{-6}$ and an annual expansion rate of $70 \times 10^{-6}$. The studies about the dam structural behavior are still being carried out.

In January 2001, during the site inspection which took place immediately after a second dam overtopping, a set of cracks was identified, in addition to the already known map cracking in some sections of the structure.

Following that first assessment, a complete research program was started in 2006 in order to identify the causes of damage of the concrete. The objectives of the work included the characterization of the concrete at the present and the evaluation of future expansion potential. Core samples were extracted and examined for the presence of expansive reactions and its extent. A number of tests were suggested, which included the microscopic observations by optical and scanning electron microscope (SEM), the determination of soluble alkalis and sulfates, the residual potential for alkali-induced and/or internal sulfate-induced expansion mechanisms, and the 
Fig. 2 Main results of statistical model of the vertical displacements observed in the different concrete blocks in 2000, 2007, 2012, and the prevision for 2025 . The largest displacement is observed in the right arch dam and is increasing. The displacements are due to expansion

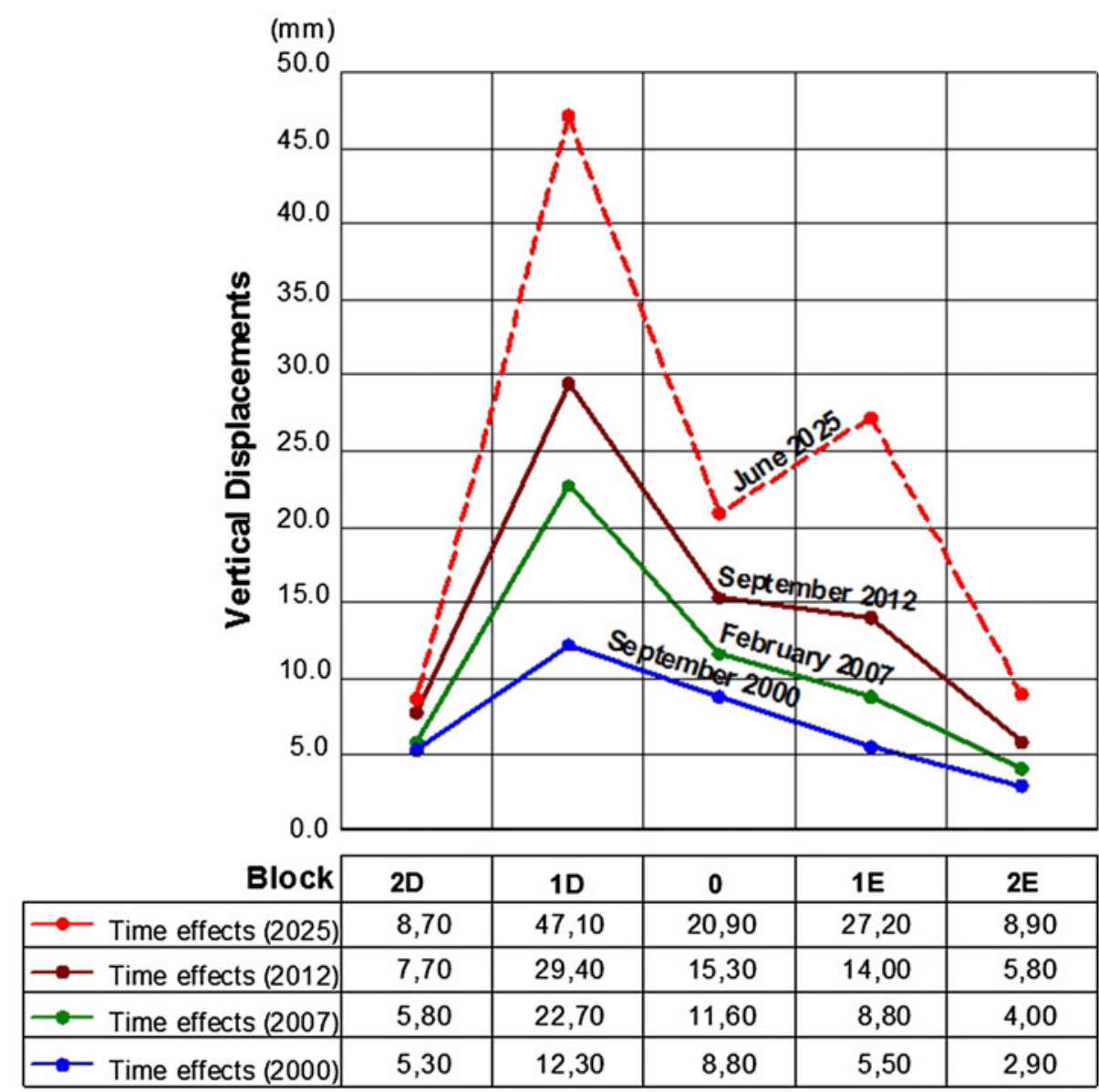

evaluation of the mechanical characteristics of the concrete. The characterization by petrographic methods intended to find out the possible reactivity of the limestone, either alkali-carbonate reactions (ACR) or alkalisilica reactions (ASR), based on the literature about carbonate rocks. The occurrence of alkali-aggregate reaction with carbonate rocks has been investigated since the 1960s [e.g., 1, 2], but the discussion about the processes involved still stands. According to Poole [3], alkali-aggregate reactions of carbonate rocks could be subdivided into (1) carbonate reaction with calcitic limestone, which produced dark reaction rims in the margin of the particles; (2) reaction with dolomitic limestone, characterized by distinct reaction rims within the aggregate; and (3) reactions involving fine grained dolomitic limestone containing interstitial calcite and clay. The subdivisions presented by Katayama [4] were similar to these stating that the reaction (2) involved dedolomitization and that (3) would be ASR of various carbonate rocks. Poole [3] also referred that numerous cases were reported where ASR and ACR occurred together in concrete. The reaction in group (1) showed micro-cracking and might be expected to reduce the bond strength between the cement and aggregate unless there was the formation of additional calcium hydroxide. In the case of dolomitic aggregates, the author explained that there was clay either as intergranular material or as inclusions within the carbonate crystallites. An important conclusion in [5], in revision of published references on ACR before 1992, was that deleterious expansion of the dolomitic aggregates was likely due to the ASR of cryptocrystalline quartz and that dedolomitization did not produce expansion [6]. In Katayama [4], the author defended that dedolomitization was a volume-decreasing reaction and also the carbonation of the cement paste in the carbonate halos was a volume-decreasing process and that the phenomena observed with dolomitic aggregates, conventionally recognized as ACR, could be explained in terms of ASR and dedolomitization. Other works have been published related to the discussion of the existence of ACR such as [7-9]. Grattan-Bellew et al. [10] referred to the occurrence of ASR in Kingston rock and concluded that ACR was a variant of ASR.

This study involved microscopic, chemical and mechanical tests and a multidisciplinary approach, of which the results were summarized in the present paper. 


\section{Materials and Methods}

\section{General}

A complete program of drill coring of the concrete was designed with the intent of performing a number of tests, as referred above, such as microscopic examinations, soluble alkalis and sulfate evaluations, residual expansion tests, and unconfined compression tests. The cores were extracted by drilling equipment cooled by water. Long cores were extracted from the dam wall in order to determine the properties of the concrete. The cores for mechanical testing were of about $150 \mathrm{~mm}$ in diameter, and they were $76 \mathrm{~mm}$ for all the other tests and analyses. The length of the cores was variable, depending on the section in the structure in which they were located. Table 1 lists details about the cores drilled, their location, and the objectives of each core. In Fig. 1, the locations of the drill cores are indicated also showing that they cross the dam body from the crest to a depth close to the contact with the foundation rock mass.

The concrete cores were labeled with a reference number and the sample's orientation indicated with waterproof ink. To avoid desiccation, cores were wrapped in cling film and sealed in polyethylene bags. They were immediately taken to the laboratory.

Once in the laboratory, cores were placed in a moist room at $20 \pm 3{ }^{\circ} \mathrm{C}$ and were afterward cut with a diamond blade in different segments with length of 120-160 mm to be allocated for the various tests.

The portions for petrographic analysis were cut in half lengthwise in order to observe the concrete. This observation allowed the selection of the sites for the production of thin sections, namely where reaction rims, filled air voids, and cracks were detected by the macroscopic analysis. Several thin sections were produced from each core in order to be representative of the concrete in the respective core. Additional sites were selected for reference in places where the concrete seemed sound and in pristine conditions.

At beginning and at the conclusion of the residual expansion tests, some pieces of concrete were examined by SEM and energy dispersive spectrometry (EDX) to confirm the type, localization, and extent of deleterious products in the material.

Exudation samples from the surface of the cores were also collected and examined by SEM/EDX in order to determine the semi-quantitative element composition.

\section{Materials and Mix Designs}

According to the information available about the construction, the concrete applied in the dam was a readymixed concrete of the class of resistance C16/20 [11] with a CEM I type cement content of $360 \mathrm{~kg} \mathrm{~m}^{-3}$. Aggregates were of two types: a coarse aggregate fraction, with maximum dimension of $50 \mathrm{~mm}$, composed of crushed limestone and rare particles of siliceous composition, and a siliceous fine fraction (sand), from an alluvial deposit. Due to various reasons related to the evolution of the companies involved in the construction of the dam, it was not possible to identify the exact area of the quarry or the natural deposit of provenance of the aggregates.

\section{Methods for Assessment and Analysis}

\section{Petrographic Microscope Observations}

Petrographic analysis of the concrete included macroscopic assessment of the concrete cores as extracted, prior to thin sectioning or other preparation.

Table 1 List of the drill cores obtained for the study of deterioration of the concrete of the dam and the number of tests performed in each drill core

\begin{tabular}{|c|c|c|c|c|c|c|c|}
\hline \multirow{2}{*}{$\begin{array}{l}\text { Drill core } \\
\text { reference }\end{array}$} & \multirow{2}{*}{$\begin{array}{l}\text { Total } \\
\text { length }(\mathrm{m})\end{array}$} & \multirow{2}{*}{$\begin{array}{l}\text { Petrographic } \\
\text { analyses }\end{array}$} & \multirow{2}{*}{$\begin{array}{l}\text { Unconfined } \\
\text { compression } \\
\text { tests }\end{array}$} & \multirow{2}{*}{$\begin{array}{l}\text { Soluble } \\
\text { alkali content }\end{array}$} & \multicolumn{2}{|c|}{ ASR residual expansion } & \multirow{2}{*}{$\begin{array}{l}\text { Residua } \\
\text { internal } \\
\text { sulfate }\end{array}$} \\
\hline & & & & & Water & $\mathrm{NaOH} 1 \mathrm{~N}$ & \\
\hline 1 & 9.60 & 3 & $\ldots$ & 3 & 6 & 3 & $\ldots$ \\
\hline 2 & 5.00 & $\cdots$ & 1 & $\cdots$ & $\cdots$ & $\ldots$ & $\cdots$ \\
\hline 3 & 14.15 & 4 & $\cdots$ & 4 & 7 & 4 & 1 \\
\hline 4 & 5.00 & $\cdots$ & 1 & $\cdots$ & $\cdots$ & $\cdots$ & $\cdots$ \\
\hline 5 & 27.30 & 6 & $\cdots$ & 6 & 8 & 4 & 2 \\
\hline 6 & 5.00 & $\cdots$ & 1 & $\cdots$ & $\cdots$ & $\cdots$ & $\cdots$ \\
\hline 7 & 27.00 & 7 & $\cdots$ & 6 & 10 & 6 & 2 \\
\hline 8 & 14.15 & 4 & $\cdots$ & 4 & 5 & 3 & 2 \\
\hline 9 & 5.00 & $\cdots$ & 1 & $\cdots$ & $\cdots$ & $\cdots$ & $\cdots$ \\
\hline 10 & 8.2 & 3 & $\cdots$ & 3 & 4 & 2 & 2 \\
\hline 11 & 20.95 & 5 & $\ldots$ & 5 & 6 & 4 & 2 \\
\hline
\end{tabular}


During storage, white exudations were formed at the surfaces of some of the cores. Samples of these exudations were glued with araldite to metallic cylinders $6 \mathrm{~mm}$ diameter, submitted to vacuum, and sputtered with gold for characterization by SEM/EDX.

Slices of the concrete were cut and glued with araldite to a glass slide to produce thin sections measuring $25 \times 45 \mathrm{~mm}$. The samples were impregnated with resin without application of vacuum. Thin sections of $30 \mu \mathrm{m}$ thickness were produced by hand methods using several stages of grinding and lapping with powdered silicon carbide until final polishing with diamond grit. The thin sections were polished for examination by SEM and for qualitative analysis by EDX.

Thin sections were observed under a petrographic microscope in plane polarized light (PPL) and crossed polarized light. Locations of alkali-silica gel were identified with ink on the thin section surfaces. The thin sections were then sputter-coated with carbon under vacuum for analysis by SEM equipped with field-emission gun (FEG) and an EDX. Acceleration voltage was set to $15 \mathrm{kV}$, beam current to $10 \mathrm{nA}$, and working distance of $15 \mathrm{~mm}$. The collection time for the microanalyses was $60 \mathrm{~s}$ with a dead time of approximately $30 \%$. Spot size was set to $10 \mathrm{~nm}$ for qualitative analysis.

\section{Content of Soluble Alkalis}

About $250 \mathrm{~g}$ of concrete was crushed and reduced to pass $160 \mu \mathrm{m}$. It was oven-dried at $40{ }^{\circ} \mathrm{C}$ for one day and reduced by manual splitting to $\sim 50 \mathrm{~g}$ sufficient samples to fill a porcelain vibratory ball mill for pulverization. Alkalis determination was conducted following the methodology developed by [12], with sodium and potassium contents determined separately on an atomic absorption spectrometer. The sodium and potassium contents are expressed as sodium equivalent $\left(\mathrm{Na}_{2} \mathrm{O}_{\text {eq. }}\right)$ according to the expression: $\mathrm{Na}_{2} \mathrm{O}_{\text {eq. }}=\mathrm{Na}_{2} \mathrm{O}+0.658 \times \mathrm{K}_{2} \mathrm{O}$, where the constant 0.658 is from the ratio of the atomic mass of $\mathrm{Na}_{2} \mathrm{O}$ to $\mathrm{K}_{2} \mathrm{O}$.

\section{Residual Alkali-Silica Reactivity of Concrete}

Concrete cores $76 \mathrm{~mm}$ diameter and $160 \mathrm{~mm}$ in length were tested according to [13] test method. Of the 72 specimens tested, 26 were tested with external supply of alkalis (Table 1). In this method, the specimens, previously wrapped in absorbent paper and polyethylene sheet, were placed in a closed metal container, with a water or $1 \mathrm{M}$ $\mathrm{NaOH}$ solution in the bottom, and stored in a climatic chamber at $38{ }^{\circ} \mathrm{C}$. The specimens were placed in a vertical position with the lower end of the cores approximately $25 \mathrm{~mm}$ above the surface of the water or $\mathrm{NaOH}$ solution in the containers. The measurements were made at various intervals over the period of 1 year, with a gauge length comparator $(0.001-\mathrm{mm}$ resolution) adapted to the shape of the reference studs installed at the ends of each core. At the end of these tests, some specimens were crushed for assessment by SEM/EDX analysis. The samples were sputtered with gold-palladium in a vacuum evaporator to avoid charging effects.

\section{Residual Internal Sulfate Reactivity of Concrete}

Concrete cores, with the same dimensions of those previously mentioned, were tested according to the French test method LPC no 67 [14] and [15]. In this method, the expansion was obtained by lateral length measurements in three equally spaced lines of two gauge reference studs each, with a distance of $100 \mathrm{~mm}$ between the two studs of a given line, thus permitting three readings per core. In this test, and in contrast to what occurred in ASR residual expansion tests, the specimens were immersed in tap water at $20 \pm 2{ }^{\circ} \mathrm{C}$, the water level in the container being controlled in order to reduce the concrete leaching. The expansion measurements were made at regular intervals with a gauge length comparator adapted to the reference studs installed in the three lateral lines of each core. As in the ASR residual reactivity, 1 year after immersion, some of the core specimens were analyzed at the SEM/EDX.

\section{Mechanical Tests}

Mechanical tests were carried out on core samples measuring $150 \mathrm{~mm}$ diameter (core numbers 2, 4, 6, and 9). Unconfined compression and splitting tensile tests were performed compliant with Portuguese standard [16] on cylindrical samples of $150 \mathrm{~mm}$ height. Concrete cylinders with $600 \mathrm{~mm}$ height were used in the elasticity modulus determination, performed according to the Portuguese standard [17].

\section{Results}

\section{Site Inspection}

The inspection of the concrete surfaces showed that there was cracking and discoloration in some sections of the structure, more prominent in the downstream faces of the lateral arches and in the spillway surfaces. In the upstream face and in the surface of the spillways, there was a set of horizontal fissures and also intense map cracking (Fig. 3). The concrete surface was not smooth and showed features of dissolution both of the cement paste and of some of the aggregate particles. There were siliceous grains of the fine aggregate that were exposed and protruding from the 
surrounding paste. The buttresses also had map cracking which was particularly intense in the northern faces. Rare exudations composed of calcium carbonate were found, some associated with the horizontal cracks.

\section{Macroscopic Analysis of Concrete Cores}

The concrete cores were visually in a sound state and showed homogeneous distribution of the aggregate particles throughout the material. Some cores showed a higher porosity, and in others there were voids with irregular shapes located in spaces between particles of coarse aggregate, where cement paste seems not to have penetrated. There were light-colored rims on the aggregate boundaries and rare, brownish rims in the cement paste around some particles of the coarse aggregate.

Rare fine cracks were identified in the cement paste and partially around the boundaries of some coarse aggregate particles. Some voids showed a white lining.
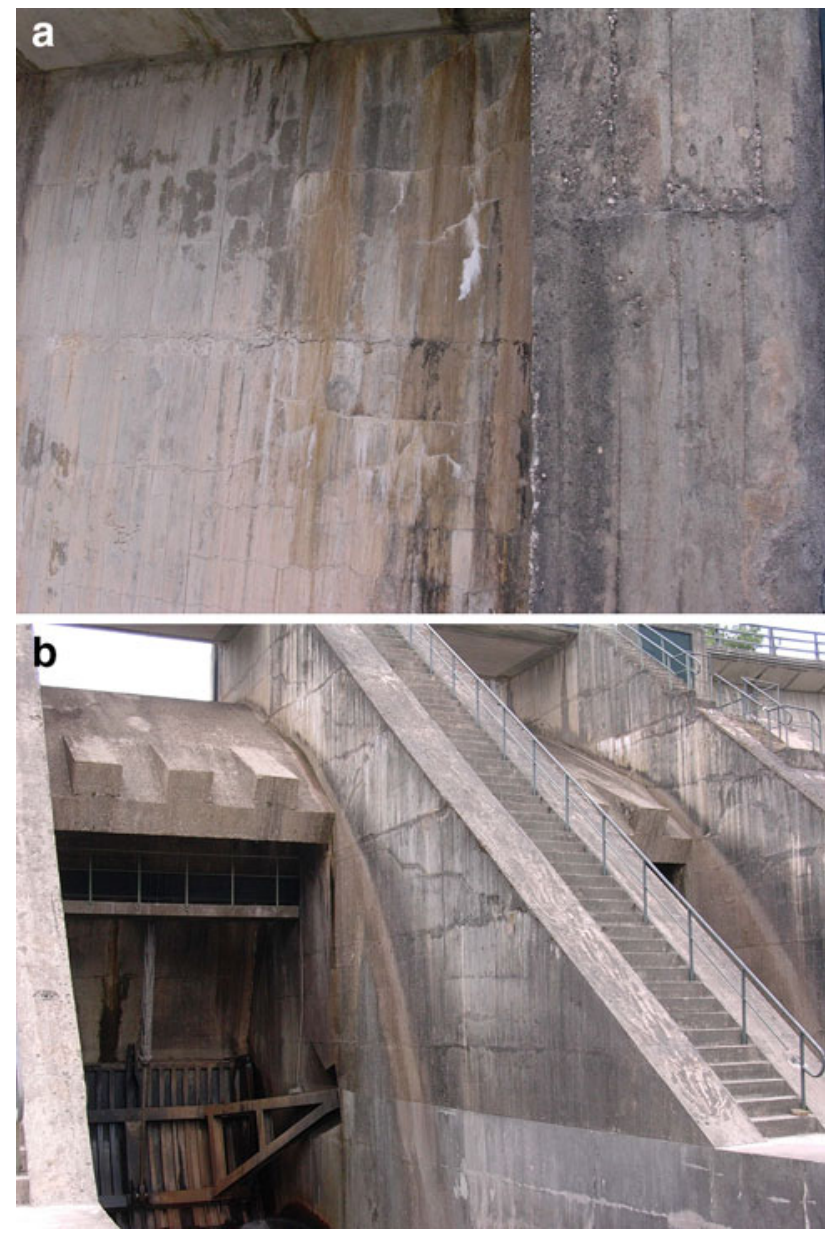

Fig. 3 Horizontal cracks and map cracking in the vertical wall close to the right and in the central buttress
Aggregates were mainly composed by angular and elongated particles of a carbonate rock and also some siliceous rock fragments. The $D_{\max }$ of coarse aggregates was of $30-50 \mathrm{~mm}$, as measured in the halved cores.

\section{Petrographic Microscope Observations}

The petrographic analysis was conducted with two objectives: (1) evaluation of the potential reactivity of aggregates to alkalis and (2) the detection of microscopic manifestations of deleterious products in the concrete.

The optical microscope was used for the identification of the fragment types (petrography of coarse and fine aggregate), the observation of the relationship between the aggregate and the cement paste, the type and location of voids and cracks as well as the study of features related to the presence of deleterious expansive products.

\section{Potential Reactivity of Aggregates}

The composition and nature of the aggregates were confirmed by the examination of thin sections. The coarse and fine aggregate components were very similar for all the cores. The coarse aggregates were composed dominantly by micritic (carbonated mudstone) limestone containing veinlets of sparitic (crystalline) calcite. Some grains exhibited rims in the boundaries where there were individualized crystals with interstices filled by a matrix of brownish minerals. The nucleus always contained micritic limestone.

The coarse fraction also included some well-rounded siliceous particles composed of various forms of polycrystalline quartz. Some grains contain microcrystalline quartz and are classified as potentially reactive according to RILEM AAR-1 test method [18] and also by the Portuguese standard [19].

The sand fraction particles were dominantly well rounded, rich in monocrystalline and polycrystalline quartz. The quartz grains included microcrystalline textures and strained quartz with sutured boundaries, features that indicated they were susceptible to AAR. There were also grains formed by silicate minerals, such as K-feldspar, plagioclase, biotite, chlorite, muscovite, epidote, tourmaline, and opaque minerals. There were also rock fragments such as granite, limestone, and schist randomly distributed in the concrete.

\section{Manifestations of Deleterious Internal Reactions}

The most prominent characteristic of the concrete was the presence of micro-cracking in the interfaces between coarse aggregate particles and the cement paste. These cracks reached in some places $120 \mu \mathrm{m}$ in width were 
discontinuous around the aggregate pieces and some extended into the cement matrix. The frequency of microcracks varied from core to core and also in different thin sections along each core. Most of the cracks in the interfaces cement paste-aggregate particles were filled by crystals of ettringite growing perpendicular to the walls (Fig. 4). Ettringite crystals were also present in voids and in the cement paste. The localization and morphology of the ettringite crystals are a feature associated with an internal sulfate reaction (ISR) or delayed ettringite formation (DEF) caused by cement type, concrete mix design, and curing temperature, being the most common neoformation product in the concrete of the dam. In fact, the cement dosage used in the concrete is quite unusual in a concrete dam, being for sure the main reason for this internal reaction. Besides petrographic observations, SEM/ EDX analysis confirmed the presence of veins of massive ettringite in aggregate/paste interfaces, voids, etc.

Besides the aggregate particles de-bonded from the cement paste, there were other limestone particles showing diffuse boundaries or rims. In order to find out whether there was dolomite, micro-silica, or clay minerals within the limestone, SEM/EDX analyses were performed. X-ray mapping by EDX at magnification $\times 100 \mu \mathrm{m}$ of several elements $(\mathrm{Si}, \mathrm{Al}, \mathrm{Na}, \mathrm{K}, \mathrm{Mg})$ revealed the existence of silicon, aluminum, low contents of sodium, potassium, and magnesium in the interstices of the calcite crystals, which suggests the presence of clay minerals (Fig. 5). Dolomite was not detected. No alkali-silica gel was identified in relation to these rims. Inside the limestone, remains of fossils were observed filled by a mineral of radial texture and low birefringence. It was concluded by SEM/EDX that the fossils were filled by chalcedony and calcium carbonate. The EDX spectra and the semi-quantitative composition of the material that constituted these fragments were indicative of the presence of ASR gel (Fig. 6).

Cracks were observed crossing the cement paste and going across some of the siliceous aggregate particles. The presence of ASR gel was heterogeneous along the structure and along each concrete core. The gel was present in some cracks but dominantly replaced siliceous particles of the sand fraction. A colorless isotropic gel could be observed in the rims of the particles and voids, with typical shrinkage cracks. When replacing particles, the gel is brownish. SEM/EDX observation showed that the gel was composed mainly of silicon, calcium, potassium, and some aluminum, sodium, and magnesium (Fig. 7), with some differences in the intensity of the elements from the interior to the boundaries of the aggregate particles.

The exudation formed at the surface of the core number 11 was also composed of ASR gel, as confirmed by SEM/ EDX.
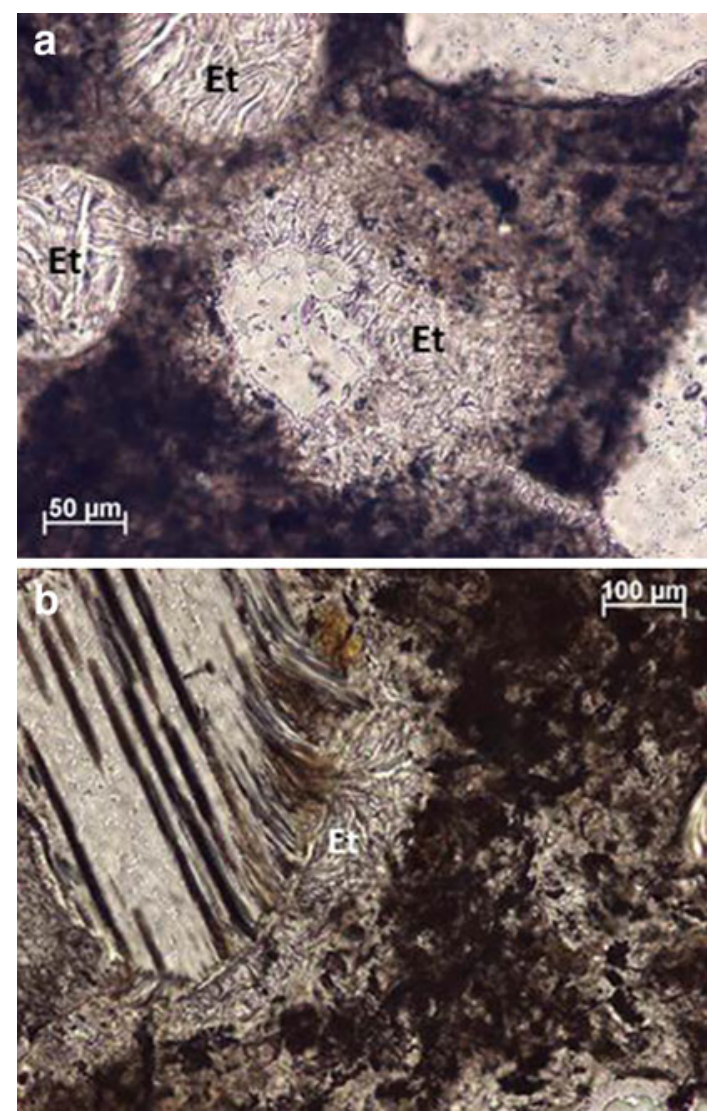

Fig. 4 Ettringite (Et) crystals (acicular): filling voids and around a sand fraction particle; in the interface of a mica plate within the cement paste (images obtained under PPL)

\section{Soluble Alkalis Content}

In order to determine whether the alkalis content would be sufficient to maintain the ASR and to evaluate possible variations on soluble alkalis in the structure, specimens were selected, which were located close to the sites where samples for residual expansion were taken. It was verified that the higher alkali soluble contents were obtained in core number 11, which was located at a greater distance from the upstream wall than the other cores. This core was the one where damage due to internal expansive reactions was more intense.

Assuming a concrete density of $2400 \mathrm{~kg} \mathrm{~m}^{-3}$, values of 1.73 and $3.00 \mathrm{~kg}$ of $\mathrm{Na}_{2} \mathrm{O}_{\text {eq. }} \mathrm{m}^{-3}$ were obtained for the concrete in the arch sections, with a larger range of values in the left section. The values calculated for the buttresses varied from 1.62 to $4.28 \mathrm{~kg}$ of $\mathrm{Na}_{2} \mathrm{O}_{\text {eq. }} \mathrm{m}^{-3}$.

\section{Residual Alkali-Silica and Internal Sulfate Reactivity}

In order to assess the future behavior of the affected structure, measurements of residual expansion were 

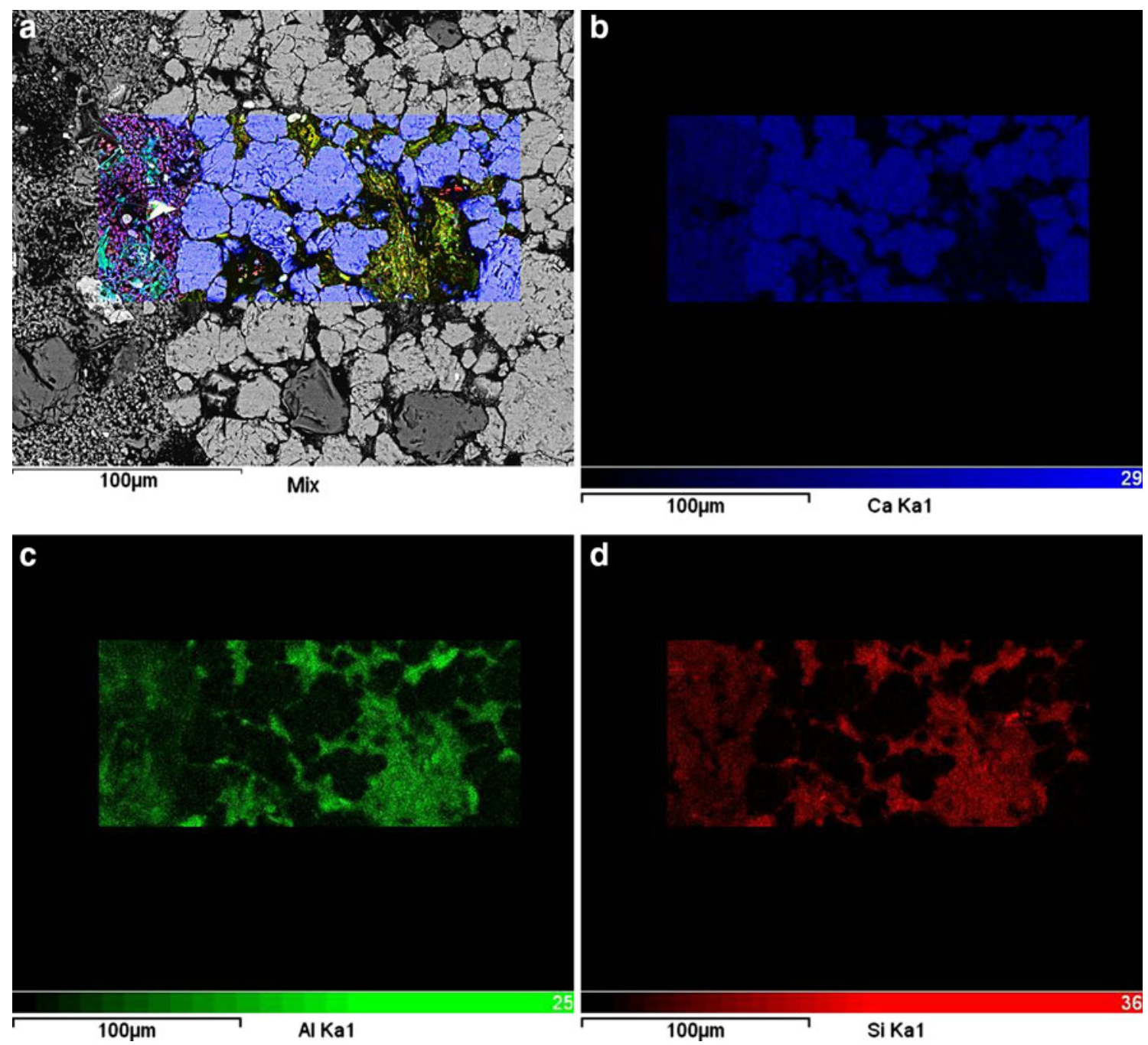

Fig. 5 Interfaces between a coarse aggregate particle of limestone and the cement paste. The rims of the particles of limestone are composed of larger crystals of calcite. The element maps show the

performed. These measurements are usually carried out during the diagnosis of ASR-affected structures.

The results of the tests for assessing the potential for further ASR expansion are presented in Table 2. The values obtained were compared with the test criteria: $<100 \times 10^{-6}$-negligible; $100-500 \times 10^{-6}$-moderate and $>500 \times 10^{-6}$-important [13]. It was verified that specimens exposed to water moisture experienced higher values of residual expansion than those stored in the sodium solution moisture.

The specimens were observed by SEM after the completion of the tests which revealed the presence of ettringite in all specimens, occurring in a compressed form in the paste-aggregate interfaces, which was attributed to an ISR (Fig. 8). Besides the presence of ettringite, some ASR products were detected, with characteristic shrinkage cracks and a smooth surface.

composition of the crystals $(\mathrm{Ca})$ and of the materials in the interstitial spaces $(\mathrm{Si}, \mathrm{Al})$. These materials correspond to clay minerals (image by SEM; maps of elements obtained by EDX at CEMUP)

The potential for residual expansion due to ISR was higher than that obtained for the ASR (Table 3) and might be high enough to continue the degradation of the concrete. This interpretation was based on the expansion limit of $0.04 \%$ at 1 year defined in the French recommendations [20] for evaluating the susceptibility of the concrete compositions to ISR. The results of residual ISR showed, contrary to that of residual ASR, a behavior very similar for the different cores, suggesting that the ISR has been the main cause of expansion of the concrete.

\section{Mechanical Tests}

In order to evaluate the present characteristics of the concrete, mechanical tests were performed on samples from the arch sections and from the buttresses of the dam. 


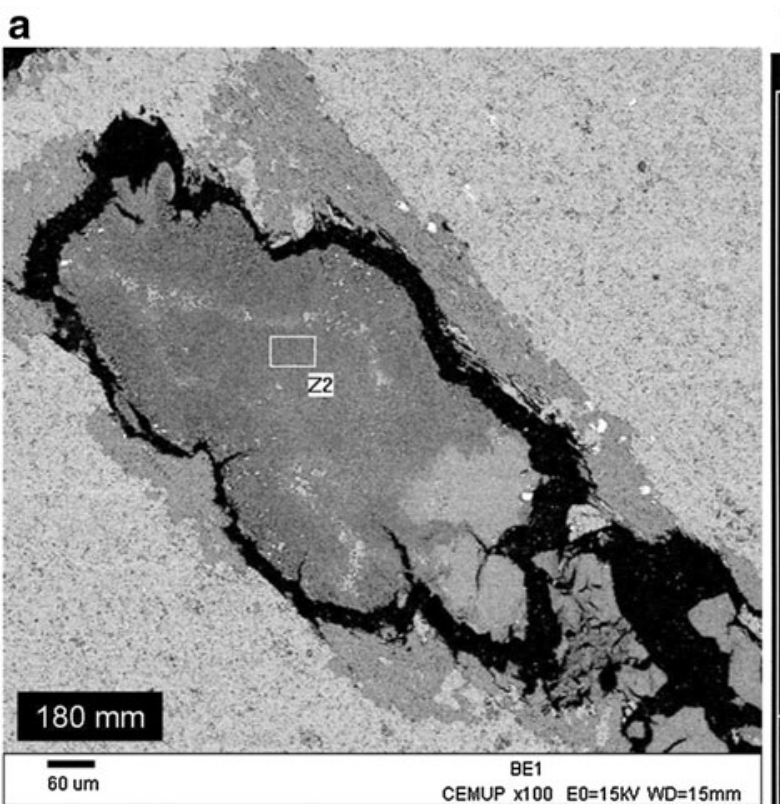

\section{b}

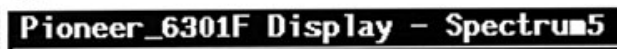

VFS: 2800

Livetime: 60

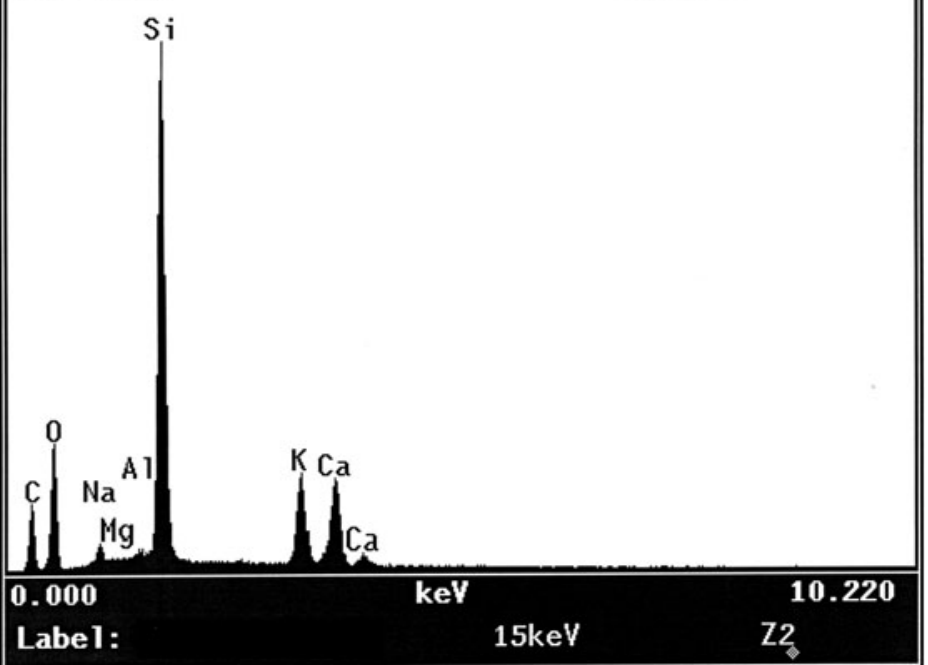

C

\begin{tabular}{lrr}
\hline & Weight \% & \multicolumn{1}{c}{ Atomic \% } \\
\hline $\mathrm{Si}$ & $30.28 \pm 0.23$ & 24.02 \\
\hline $\mathrm{K}$ & $10.66 \pm 0.28$ & 6.07 \\
$\mathrm{Na}$ & $1.92 \pm 0.10$ & 1.87 \\
\hline $\mathrm{Ca}$ & $13.45 \pm 0.20$ & 7.48 \\
\hline $\mathrm{O}$ & 43.19 & 60.15 \\
\hline Total & 100.00 & 100.00 \\
\hline
\end{tabular}

Fig. 6 Fossil fragments included in a particle of micritic limestone and containing chalcedony. The EDX analysis shows the presence of Si, Ca, $\mathrm{K}$, and $\mathrm{Na}$ (image in SEM and spectrum by EDX obtained by CEMUP)

The results for unconfined compression showed a high compressive strength of the concrete. The average value, for a 22 years old concrete, was of $33.7 \mathrm{MPa}$ and the minimum was $21.1 \mathrm{MPa}$, when referenced to cubes measuring $200 \mathrm{~mm}$ on a side. These values allow the assumption, according to [11], that the concrete may belong to $\mathrm{C} 16 / 20$ or $\mathrm{C} 20 / 25$ class of concrete, this last one higher than that defined in the design of the structure. Considering that the initial compressive strength of the concrete should correspond to the values defined in [11], regardless of the class, it can be concluded that the deterioration process did not significantly affect the compressive strength of the concrete.

Concerning the tensile strength, an average of $3.0 \mathrm{MPa}$ was obtained and a minimum of $2.25 \mathrm{MPa}$ achieved by the splitting test, which indicated that, supposing a C20/25 concrete, the tensile strength was a little lower than expected. The elasticity modulus was obtained on four samples and presented values between $19.1 \mathrm{GPa}$, in the left buttress, and $24.4 \mathrm{GPa}$. A value of $31.4 \mathrm{GPa}$ was obtained in a specimen with $500 \mathrm{~mm}$ height.

\section{Discussion}

Considering the results of all the tests presented above, it was necessary to understand the main cause of deterioration of the concrete of the dam. The site inspection and the visual observation of the concrete cores revealed the existence of features related to the occurrence of AAR. The damp patches and brownish rims around some of the aggregate particles observed in the concrete cores were consistent with this conclusion.

Portuguese limestones have been reported as potentially alkali reactive [21], and some cases of AAR with this type of rocks have been identified [22].The present work was 

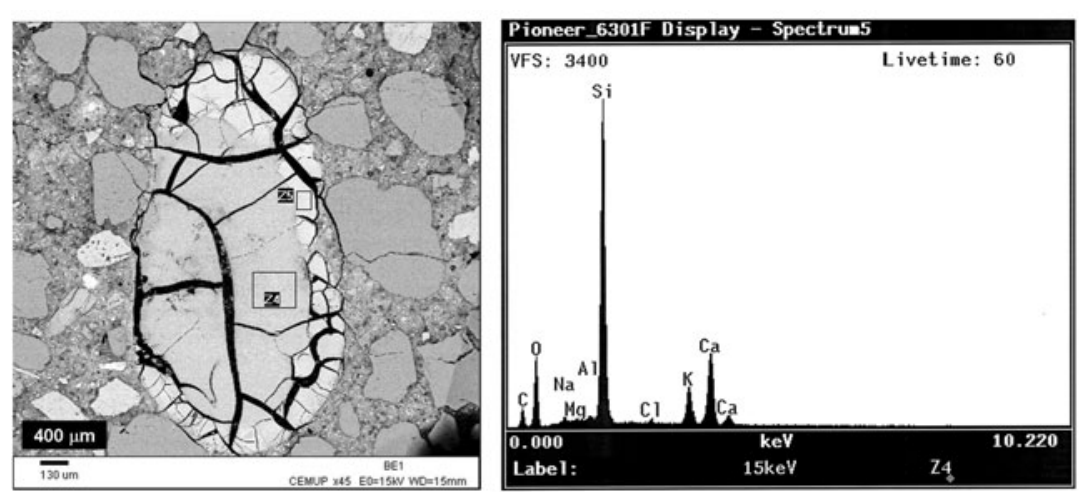

Z4

\begin{tabular}{lrr}
\hline & Weight \% & \multicolumn{1}{c}{ Atomic \% } \\
\hline Si & $29.60 \pm 0.21$ & 23.60 \\
\hline $\mathrm{K}$ & $6.88 \pm 0.22$ & 3.94 \\
$\mathrm{Na}$ & $0.97 \pm 0.08$ & 0.94 \\
$\mathrm{Ca}$ & $17.88 \pm 0.20$ & 9.99 \\
$\mathrm{O}$ & 43.25 & 60.53 \\
\hline Total & 100.00 & 100.00 \\
\hline
\end{tabular}

Z5

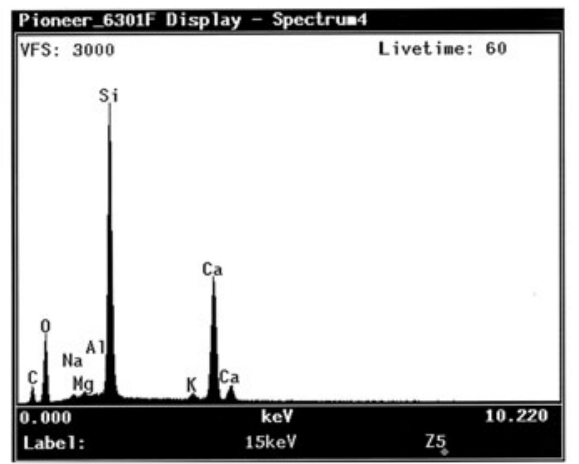

\begin{tabular}{lrr}
\hline & \multicolumn{1}{c}{ Weight \% } & \multicolumn{1}{c}{ Atomic \% } \\
\hline Si & $26.54 \pm 0.19$ & 21.50 \\
$\mathrm{~K}$ & $1.05 \pm 0.08$ & 0.61 \\
$\mathrm{Na}$ & $0.63 \pm 0.08$ & 0.63 \\
\hline $\mathrm{Ca}$ & $28.54 \pm 0.37$ & 16.20 \\
$\mathrm{O}$ & 42.55 & 60.50 \\
\hline Total & 100.00 & 100.00 \\
\hline
\end{tabular}

Fig. 7 Alkali-silica gel replacing completely a siliceous particle of the sand fraction: The composition of the gel in the rim, closer to the cement paste, is richer in $\mathrm{Ca}$. Si is always the main component (SEM/EDX) (image and spectra obtained by CEMUP)

Table 2 Average residual expansion due to ASR of specimens exposed above water

\begin{tabular}{llrr}
\hline Structure section & Core Id & \multicolumn{2}{c}{ Residual expansion } \\
\cline { 3 - 4 } & & $10^{-6}$ & $\%$ \\
\hline Right arch & $\mathrm{C} 1$ & 242 & 0.02 \\
\multirow{2}{*}{ Right buttress } & $\mathrm{C} 3$ & -18 & 0.00 \\
\multirow{2}{*}{ Left arch } & $\mathrm{C} 5$ & 72 & 0.01 \\
& $\mathrm{C} 11$ & -52 & -0.01 \\
Left buttress & $\mathrm{C} 8$ & 28 & 0.00 \\
& $\mathrm{C} 10$ & 40 & 0.00 \\
& $\mathrm{C} 7$ & -6 & 0.00 \\
\hline
\end{tabular}

focused on the determination of the phenomena in the origin of the deterioration and also on the extent of the damage because there was a suspicion about the possibility of occurrence of both ACR and ASR. The composition of the limestone that constitutes the coarse aggregate was assessed in order to identify reactive minerals as well as the types of reactions and reaction products. Under optical microscope, some particles exhibited a white halo in the contact with the cement paste, followed by a darker rim in the interior of the particle. This carbonate halo showed larger crystals of calcite than those in the interior of the particle, but no dolomite was identified. However, optically the discolored rims observed in some of the limestone particles were similar to those described by Katayama [4] for Austrian dolostones, consisting of a mosaic texture of coarse-grained dolomite crystals.

It was also verified that in some carbonate particles, mainly those with larger calcite crystals in rims in the boundaries, there was a reaction between the cement paste and the aggregate, the interface becoming irregular and undefined. The diffuse limits between the limestone grains and the cement paste and also the rims around some aggregate grains resemble the rims due of ACR of nondolomitic limestones as referred by $[4,5])$. However, the EDX analysis performed did not reveal the presence of significant $\mathrm{Mg}$ above the detection limit ( 0.1-10 wt.\%), which confirms that the limestone particles were not dolomitic. Regarding ASR, although there was chalcedony inside the fossil fragments and dispersed microcrystalline silica and silicate minerals in the interstices of calcite crystals, there were no cracks or other signs of expansion related to these features, and it was concluded that the ACR and ASR were not due to the coarse aggregate.

The petrographic analysis confirmed the existence of potentially alkali-reactive particles in the sand fraction. ASR gel was identified replacing siliceous particles, in 

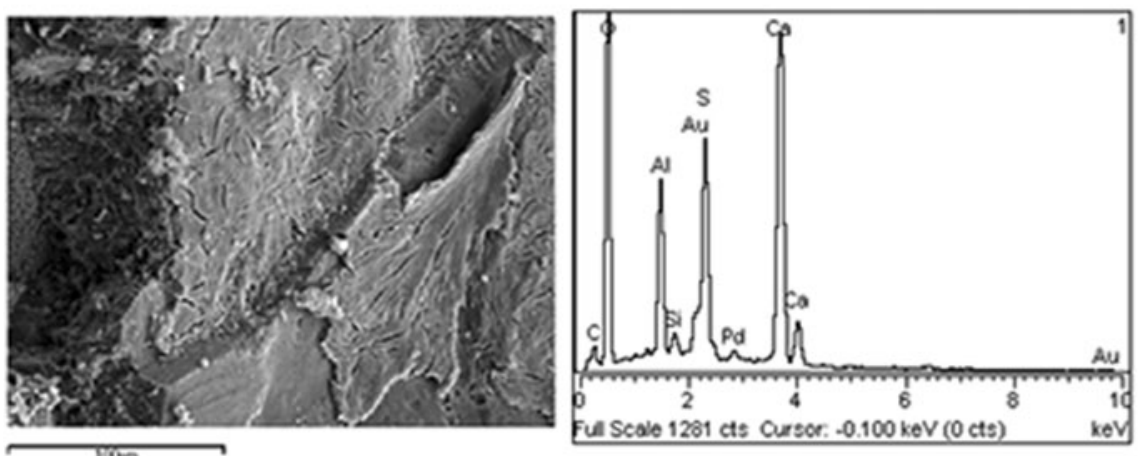

\begin{tabular}{lrr}
\hline & Weight \% & \multicolumn{1}{c}{ Atomic \% } \\
\hline Al & $6.06 \pm 0.12$ & 4.85 \\
\hline S & $8.06 \pm 0.18$ & 5.42 \\
\hline C & $5.12 \pm 0.37$ & 9.19 \\
\hline Ca & $34.99 \pm 0.35$ & 18.83 \\
\hline O & $45.77 \pm 0.46$ & 61.71 \\
\hline Total & 100.00 & 100.00 \\
\hline
\end{tabular}
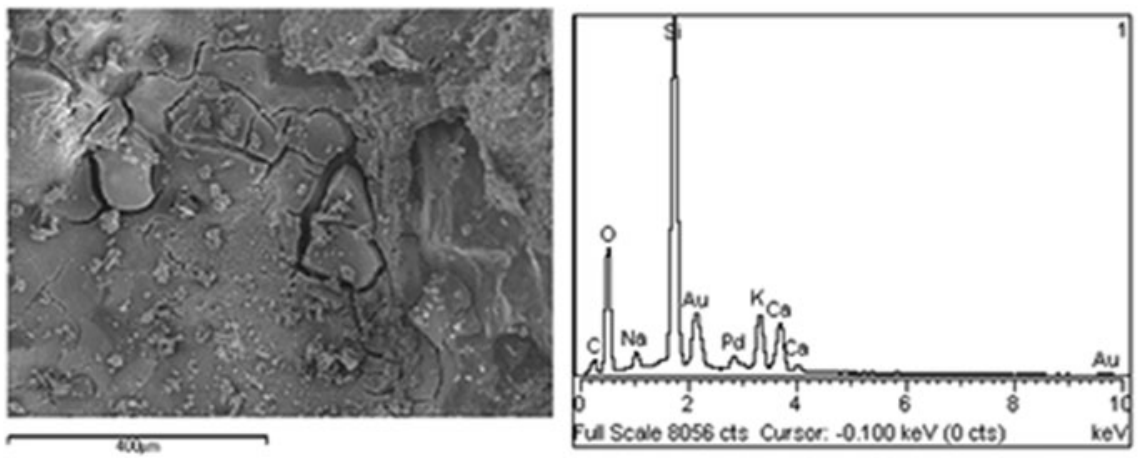

\begin{tabular}{lrr}
\hline & Weight \% & Atomic \% \\
\hline $\mathrm{Si}$ & $21.42 \pm 0.53$ & 14.01 \\
\hline $\mathrm{K}$ & $6.31 \pm 0.18$ & 2.97 \\
\hline $\mathrm{Na}$ & $1.50 \pm 0.09$ & 1.20 \\
\hline $\mathrm{Ca}$ & $6.15 \pm 0.18$ & 2.82 \\
\hline $\mathrm{C}$ & $12.69 \pm 2.06$ & 19.40 \\
\hline $\mathrm{O}$ & $51.93 \pm 1.26$ & 59.61 \\
\hline Total & 100.00 & 100.00 \\
\hline
\end{tabular}

Fig. 8 Samples observed by SEM after the residual alkali-silica reactivity tests. Spectra obtained by EDX confirm the presence of ettringite and alkali-silica gel (SEM image and spectrum obtained in LNEC)

Table 3 Average residual expansion due to ISR of specimens immerged in water

\begin{tabular}{llrl}
\hline Structure section & Core Id & \multicolumn{2}{c}{ Residual expansion } \\
\cline { 3 - 4 } & & $10^{-6}$ & $\%$ \\
\hline Right arch & C3 & 106 & 0.01 \\
Right buttress & C5 & 80 & 0.01 \\
\multirow{2}{*}{ Left arch } & C11 & 115 & 0.02 \\
& C8 & 110 & 0.01 \\
Left buttress & C10 & 106 & 0.01 \\
\hline
\end{tabular}

voids and in some cracks in the cement paste, showing a heterogeneous distribution throughout the structure and also along a single core. Gel seemed to be concentrated in specific places in the structures, namely in the cores that exhibit higher porosity. The observation led to the conclusion that the occurrence of ASR was associated with the presence of siliceous particles of the sand fraction. The optical properties and the qualitative composition of the gel in cracks in the cement paste and in voids were consistent with other results published [23-25] being rich in silicon with calcium, potassium, and sodium. Besides the gel in the interior of the concrete, the presence of exudations in the surface on the cores provides evidence that ASR was present in the concrete.

By microscopy, it was observed that the most widely distributed deleterious product was expansive ettringite, which occurs with a more homogeneous distribution in the concrete, when compared to the ASR gel. The cracks formed around the coarse aggregate particles and also around some of the grains of the sand fraction were very often filled with ettringite crystals which grew perpendicularly and parallel to the crack walls. These features were compatible with DEF, and it seemed to be the main cause of deterioration in the structure.

One of the possible causes for DEF is often attributed to cement sulfates, which were unable to react completely during the hydration. This phenomenon has been increasingly reported in several countries and has been associated mainly with concrete that suffered heat treatments or developed high temperatures due to the type and dosage of cement (high contents of C3S and C3A or high heat of hydration). Studies of the DEF mechanism in these concretes pointed out that in these conditions, the solubility of calcium sulfate decreases with increasing temperature, so that the $\mathrm{C} 3 \mathrm{~A}$ is not completely combined to form the 
primary ettringite. At temperatures above $60-70{ }^{\circ} \mathrm{C}$, the primary ettringite is unstable and loses most of the water in its structure, resulting in an amorphous state compound.

Several possibilities have also been proposed to explain how these sulfates will then belatedly form expansive ettringite. The main mechanisms proposed are based on the adsorption of sulfates in the calcium silicate hydrated (CSH), which is reversible under conditions of sufficiently high humidity and which is also favored especially when ASR is presented. The formation of DEF may also occur when the concrete is subjected to high temperatures during the initial hydration, leaving the sulfates retained in the $\mathrm{CSH}$ in the form of monosulfoaluminate, which is metastable under $40{ }^{\circ} \mathrm{C}$ and may become ettringite again. Since the hardened concrete is no longer able to accommodate expansion resulting from these reactions, there will be the development of significant internal stresses, which cause micro-cracking of the concrete and, ultimately, the expansion at the macroscopic level [26-29].

Some superficial dissolution of the cement paste and of limestone aggregate particles observed during the site inspection seemed to point out also to a possible effect from polluted waters in the reservoir to add to the mechanical erosion of the water flow over the spillways.

Concerning the content of soluble alkalis test, it was verified that the values were relatively high. According to the literature (e.g., [30]), a content of $2.5-3.0 \mathrm{~kg} \mathrm{~m}^{-3}$ would be the maximum permissible to prevent deleterious ASR in concrete. It was confirmed that values exceeding that limit were obtained for the buttresses, in particular in core 11 .

The residual ASR expansion tests indicated that the specimens in water-saturated environment experienced higher values than those with added alkalis. It is assumed that the moisture caused by $\mathrm{NaOH}$ solution could be smaller than that due to the aqueous solution. However, it was still sufficient to trigger the ASR. These results could be explained essentially if the reactive silica in concrete was almost exhausted or by a higher alkali leaching process during the storage of the prisms. According to Multon et al. [31], the behavior of the concrete is always heterogeneous and several residual expansion tests must be performed to obtain significant results as those can be affected by the direction of coring compared to the casting direction and it is necessary to consider the conditions of water supply and moisture of the zones tested.

Moreover, the result from the residual ISR expansion tests was higher than that obtained for the ASR, suggesting that the ISR has been, and probably will be in the future, the main cause of expansion of the concrete.

The mechanical tests performed in this study demonstrated that the unconfined compression strength was not affected by the deterioration of the concrete but the tensile strength and the elasticity modulus were lower than expected. These conclusions are in agreement with most of the literature about the mechanical properties of concrete affected by ASR. Ono, 1989 [32], reported on the decrease in the mechanical parameters, and Takemura et al. [33] reported that ASR reduced the compressive strength about 40-50\%. Fan and Hanson [34] found that the change in the mechanical properties was closely related to the ASR expansion and also that the reduction in the splitting tensile strength was higher than that of the compressive strength. The same was stated by Swamy and Al-Asali [35] who concluded that the tensile strength is much more sensitive to ASR than the compressive strength. Similar conclusion was attained by other authors who have shown that tensile strength is a much better indicator of the progression of ASR than compressive strength [36-40] and that direct tensile strength is also more sensitive to ASR than splitting tensile strength [37, 38]. Another important work was developed by Ahmedet al. [41] who concluded that direct tensile and the static modulus of elasticity were the best indicators of reactivity, confirming the statement by Hobbs [42] that the modulus of elasticity was more affected by ASR than the compressive and the indirect tensile strengths. Marzouk and Langdon [43] investigated a potentially highly reactive aggregate and a potentially moderately reactive aggregate used in the preparation of concrete of normal- and high-strength concretes. The authors found that the direct tensile strength of both the normal-strength concrete containing the highly or the moderately reactive aggregate was very sensitive to the effects of ASR. The tensile strength of the normal-strength concrete containing the highly and moderately reactive aggregate decreased by 37 and $31 \%$, respectively.

In Fagilde dam concrete, the low values of tensile strength might be attributed to the micro-cracking, in particular the cracks formed partially around the aggregate boundaries, as observed in the concrete petrography examination. These cracks seemed to be the result of poor bonding between the two components, although the bonding and de-bonding features were not homogeneously distributed in all the concrete thin sections analyzed.

\section{Conclusions}

A wide range of tests were performed on the concrete of the dam to evaluate the cause and the extent of damage in the structure and also to study the characteristics of the aggregates involved in the reactions. According to the results above, the phenomena observed in the dam concrete, which were causing displacements, can be summarized as follows: 
- irreversible upward vertical displacements have been measured at the dam crest, indicative of a concrete expansion process;

- cracks and manifestations of dissolution of the surface concrete were identified on site;

- mechanical tests showed that unconfined compressive strength has not been affected by the deterioration of the concrete, but that damage did affect the tensile strength and the elasticity modulus of the concrete;

- cracks were frequent in the interfaces of coarse aggregate particles-cement paste;

- ASR gel was detected in cracks, voids, and mainly in substitution of siliceous sand particles, suggesting that these particles were the cause of the ASR;

- the impure limestone used as coarse aggregate contained dispersed microcrystalline silica and clay minerals in the interstices of the calcite crystals, components considered potentially alkali reactive. However, no signs of ASR were detected in connection with these features;

- some rims around carbonate particles were composed by larger crystals of calcite with diffuse boundaries between these particles and the cement paste. There were no cracks related to these boundaries;

- exudations in the concrete core surfaces were composed of ASR gel;

- expansive ettringite was widely distributed in the concrete and was abundant in voids, cracks in the boundaries of aggregate particles, and in the cement paste;

- the higher occurrence of ettringite was detected in the deeper portions of concrete cores, which seemed to be related to internal sulfate source, associated with the high dosage $\left(360 \mathrm{~kg} \mathrm{~m}^{-3}\right)$ and the cement type applied;

- the potential for residual expansion due to ISR was higher than that obtained for the ASR and might be high enough to keep the degradation of concrete mechanisms going on;

- internal sulfate attack was probably the main cause of concrete deterioration, associated with the formation of ASR gel in some sections of the dam;

- petrography analysis and the residual expansion tests were crucial in the identification of the cause of deterioration of the concrete;

- regarding the dam safety conditions, it should be noted that recent studies revealed that, currently, these conditions are guaranteed for static loads. However, the swelling progress with the same laws as those determined by the statistical model, using the vertical displacements that occurred between 1985 and 2012, allowed to predict that by 2030 , the accumulated swelling in the right arch will be of the order of $3500 \times 10^{-6}$, an amount that can compromise the safety conditions of this element. At present, a study is being conducted to evaluate the structural behavior and the dam safety conditions for dynamic actions.

Acknowledgments The authors wish to acknowledge the Fundação para a Ciência e Tecnologia (FCT) for the financial support under projects GeoREMAT and IMPROVE (PTDC/ECM/115486/2009) and also Agência Portuguesa para o Ambiente (APA) for the permission to publish the results. Some of the analyses by SEM/EDS were performed at CEMUP-Materials Centre of the University of Porto, for which equipment was funded by the projects REEQ/1062/ CTM/2005 and REDE/1512/RME/2005 of FCT.

\section{References}

1. D.W. Hadley, Alkali reactivity of carbonate rocks-expansion and dedolomitization. Proc. Annu. Meet. Highw. Res. Board 40, 462-474 (1961)

2. E.G. Swenson, J.E. Gillot, Alkali-carbonate rock reaction. Highway Research Report No. 45, pp. 21-40 (1964)

3. A. Poole, Alkali-carbonate reactions in concrete, in Proceedings of the 5th International Conference on Alkali-Aggregate Reaction in Concrete, ed. by R.E. Oberholster, Cape Town (National Building Research Institute, Pretoria, 1981), Paper S252/34

4. T. Katayama, How to identify carbonate rock reactions in concrete. Mater. Charact. 53(2-4) (Special Issue 29), 85-104 (2004)

5. T. Katayama, A critical review of carbonate rock reactions-is their reactivity useful or harmful, in Proceedings of the 9th International Conference on Alkali-Aggregate Reaction in Concrete, ed. by A.B. Poole (Concrete Society, London, 1992), pp. $508-518$

6. D.A. St. John, A.B. Poole, I. Sims, Concrete Petrography: A Handbook of Investigative Techniques, 1st edn. (Arnold Publishers, London, 1998)

7. D. Wu, K. Fang, The research of alkali reactivity of non-siliceous carbonate aggregates, in Proceedings of the 12th International Conference on Alkali-Aggregate Reaction in Concrete, ed. by T. Mingshu, D. Min (International Academic Publishers-World Publishing Corporation, Beijing, 2004), pp. 453-457

8. T. Mingshu, D. Min, Progress on the studies of alkali-carbonate reaction, in Proceedings of the 12th International Conference on Alkali-Aggregate Reaction in Concrete, ed. by T. Mingshu. D. Min (International Academic Publishers-World Publishing Corporation, Beijing, 2004), pp. 51-59

9. T. Katayama, The so-called alkali-carbonate reaction (ACR) - its mineralogical and geochemical details, with special reference to ASR. Cem. Concr. Res. 40(4), 643-675 (2010)

10. P.E. Grattan-Bellew, L.D. Mitchell, J. Margeson, M. Deng, Is alkali-carbonate reaction just a variant of alkali-silica reaction $\mathrm{ACR}=\mathrm{ASR}$ ? Cem. Concr. Res. 40, 556-562 (2010)

11. EN 206, Concrete. Part 1: Specification, performance, production and conformity. CEN (2005)

12. M.A. Bérubé, J. Frenette, M. Rivest, D. Vézina, Measurement of the alkali content of concrete using hot-water extraction, in Proceedings of the 11th International Conference on AlkaliAggregate Reaction in Concrete, ed. by M.A. Bérubé, B. Fournier, B. Durand, Québec (2000), pp. 159-168

13. Projet de méthode d'essai LPC no. 44, Alcali-réaction du béton. Essai d'expansion résiduelle sur béton durci (Alkali-silica reaction in concrete. Test for residual expansion in hardened concrete). Laboratoire Central des Ponts et Chaussées (LCPC), Paris (in French) (1997) 
14. Méthode d'essai LPC no 67, Réaction sulfatique interne au béton-Essai d'expansion résiduelle sur carotte de béton extraite de l'ouvrage (Internal sulfate reaction in concrete-Test for residual expansion on drill cores from the structure). Laboratoire Central des Pontset Chaussées(LCPC), Paris (in French) (2009)

15. A. Pavoine, L. Divet, S. Fenouillet, A concrete performance test for delayed ettringite formation: part 1 optimization. Cem. Concr. Res. 36, 2138-2143 (2006)

16. Especificação LNEC E 226, Betão. Resistência à compressão uniaxial (Concrete. Uniaxial compressive strength). LNEC, Lisbon, (in Portuguese) (1968)

17. Especificação LNEC E 397, Betão. Determinação do módulo de elasticidade (Concrete. Determination of the elasticity modulus). LNEC, Lisbon (in Portuguese) (1993)

18. I. Sims, P. Nixon, RILEM Recommended Test Method AAR-1: detection of potential alkali-reactivity of aggregates-petrographic method, TC 191-ARP: alkali-reactivity and prevention. Assessment, specification and diagnosis of alkali-reactivity. Mater. Struct. 36, 472-479 (2003)

19. Especificação LNEC E461, Betão. Metodologias para prevenir reacções expansivas internas (Concrete. Methodologies for avoiding internal expansive reactions). LNEC, Lisbon (in Portuguese) (2007)

20. M.T. Kretz, B. Godart, L. Divet (eds.), Guide technique. Recommandations pour la prévention des désordres dus à la reaction sulfatique interne (Technical guide. Recommendations for preventing deterioration due to internal sulphate attack), In Techniques et Méthodes des Laboratoires des Ponts et Chaussées, Laboratoire Central des Ponts et Chaussées (LCPC), Paris (in French) (2007)

21. J. Lindgard, M. Haugen, Experience from using petrographic analysis according to the RILEM AAR-1 method to assess alkali reactions in European aggregates. Partner Report $3.1 \mathrm{SB}$ F52A06019. Sintef, Norway (2006)

22. M.O.B. Reis, H.S. Silva, A. Santos Silva, AAR in Portuguese structures. Some case histories, in ed. by A. Shayan Proceedings of the 10th International Conference on Alkali-Aggregate Reaction in Concrete, Melbourne (1996), pp. 93-100

23. N. Thaulow, U.H. Jakobsen, B. Clark, Composition of alkali silica gel and ettringite in concrete railroad ties: SEM-EDX and X-ray diffraction analyses. Cem. Concr. Res. 26, 309-318 (1996)

24. I. Fernandes, F. Noronha, M. Teles, Microscopic analysis of alkali-aggregate reaction products in a 50-year-old concrete. Mater. Charact. 53(2-4) (Special Issue 29), 295-306 (2004)

25. A. Shayan, J. Grimstad, Deterioration of concrete in a hydroelectric concrete gravity dam and its characterization. Cem. Concr. Res. 36, 371-383 (2005)

26. L. Divet, F. Guerrier, G. Mestre, Existe-t-il un risque de développement d'une Activité sulfatique d'origine endogène dans les pièces en béton de grande masse? Le cas du pont d'Ondes (Haute-Garonne) (Is there a risk for endogenous sulphate attack in high mass concrete members. The example of the Ondes bridge (Haute-Garonne). Bulletin des Laboratoires des Ponts et Chaussées (in French), vol. 213 (1998), pp. 59-72

27. L. Divet, Les reactions sulfatiques internes: Les differents sources de sulfates, les mecanismes et les facteurs déterminants (Internal sulfate reactions: the different sources of sulfates, the mechanisms and the determinant factors), Act. Seminário Degradação de Estruturaspor Reacções Expansivas de Origem Interna, LNEC (in French) (2001)
28. A. Gonçalves, M.O. Braga Reis, Sulphate Attack of concrete, in Proceedings of the 12th European Ready Mixed Concrete Congress, Lisbon (1998), pp. 545-556

29. M. Collepardi, A holistic approach to concrete damage induced by delayed ettringite formation, in Proceedings of a Symposium Honouring Dr. Mario Collepardi, 5th CANMET/ACI International Conference on Superplasticizers and Other Chemical Admixtures in Concrete, Rome (1997), pp. 373-396

30. D.W. Hobbs, Alkali-Silica Reaction in Concrete (Thomas Telford Ltd., London, 1988)

31. S. Multon, F.-X. Barin, B. Godart, F. Toutlemonde, Estimation of the residual expansion of concrete affected by alkali-silica reaction. J. Mater. Civ. Eng. 20, 54-62 (2008)

32. K. Ono, Assessment and repair of damaged concrete structure, in Proceedings of the 8th International Conference on AlkaliAggregate Reaction in Concrete, ed. by K. Okada, S. Nishibayashi, M. Kawamura, Kyoto (1989), pp. 647-658

33. K. Takemura, M. Ichitsubo, E.Tazawa, A. Yonekura, Mechanical performance of ASR affected nearly full-scale reinforced concrete columns, in Proceedings of the 10th International Conference on Alkali-Aggregate Reaction in Concrete, ed. by A. Shayan, Melbourne (1996), pp. 410-417

34. S. Fan, J.M. Hanson, Effect of alkali silica reaction expansion and cracking on structural behavior of reinforced concrete beams. ACI Struct. J. 95, 498-505 (1998)

35. R.N. Swamy, M.M. Al-Asali, Engineering properties of concrete affected by alkali-silica reaction. ACI Mater. J. 85, 367-374 (1988)

36. G.E. Blight, J.R. McIver, W.K. Schutte, R. Rimmer, The effects of alkali-aggregate reaction on reinforced concrete structures made with witwatersrand quartzite aggregate, in Proceedings of the 5th International Conference on Alkali-Aggregate Reaction in Concrete, ed. by R.E. Oberholster, Cape Town (National Building Research Institute, Pretoria) (1981), Paper S252/15

37. N. Clayton, Structural performance of ASR affected concrete, in Proceedings of the 8th International Conference on AlkaliAggregate Reaction in Concrete, ed. by K. Okada, S. Nishibayashi, M. Kawamura, Kyoto (1989), pp. 671-676

38. T. Siemes, J. Visser, Low tensile strength in older concrete structures with alkali-silica reaction, in Proceedings of the 11th International Conference on Alkali-Aggregate Reaction in Concrete, ed. by M.A. Bérubé, B. Fournier, B. Durand, Québec (2000), pp. 1029-1038

39. B. Fournier, M.A. Bérubé, M.D.A. Thomas, N. Smaoui, K.J. Folliard, Evaluation and Management of Concrete Structures Affected by Alkali-Silica Reaction-A Review. MTL 2004-11 (OP), Natural Resources Canada, Ottawa (2004)

40. M. Ben Haha, Mechanical effects of alkali silica reaction in concrete studied by SEM-image analysis, Ph.D. thesis, École Polytechnique Fédérale de Lausanne, Switzerland (2006)

41. T. Ahmed, E. Burley, S. Rigden, A.I. Abu-Tarir, The effect of alkali reactivity on the mechanical properties of concrete. Constr. Build. Mater. 17, 123-144 (2003)

42. D.W. Hobbs, Alkali-silica reaction in concrete. Struct. Eng. 64A, 381-383 (1986)

43. H. Marzouk, S. Langdon, The effect of alkali aggregate reactivity on the mechanical properties of high and normal strength concrete. Cem. Concr. Compos. 25, 549-556 (2003) 